\title{
Penerapan Fungsi Hash dengan Algoritma RIPEMD-128 Pada Aplikasi Duplicate PDF Scanner
}

\author{
Abdurrahman Al Habib \\ Fakultas Ilmu Komputer dan Teknologi Informasi, Prodi Teknik Informatika, Universitas Budi Darma, Medan, Indonesia \\ Email: abdurrahmanalhabib@gmail.com \\ Submitted: 27/07/2021; Accepted: 13/11/2021; Published: 30/11/2021
}

\begin{abstract}
Abstrak-Perkembangan era dunia digital terus tumbuh dan semakin meningkat. Banyak industri yang sudah beralih ke teknologi digital seperti foto, video, musik, dan sebagainya. Tentunya perubahan ini membawa banyak manfaat dalam hal kecepatan dan akses data. Kemudahan dalam mengakses internet juga berpengaruh besar terhadap kehidupan manusia. Kemudahan untuk mengakses dokumen secara online sangat membantu jika ingin mencari dan mendownload dokumen berbentuk pdf secara daring. Dengan kemudahan ini banyak file pdf yang sama lebih dari satu kali terdownload. Hal ini pasti akan membebani ruang penyimpanan. Untuk membedakan file pdf yang satu dengan yang lain dilakukan dengan cara melihat dan membaca isi dari file pdf tersebut. Hal ini sangat merepotkan dan memakan banyak waktu. Untuk mengatasi hal itu maka diperlukan suatu cara praktis yang dapat digunakan untuk mencari dokumen pdf yang sama sehingga bisa menghapus file pdf yang duplikat. Salah satu cara yang dapat digunakan untuk mengatasi masalah tersebut adalah dengan memanfaatkan fungsi hash. Fungsi hash di dalam kriptografi adalah merupakan alat yang sangat penting dalam berbagai aplikasi kriptografi, sebagai contoh dalam pembentukan tanda-tangan digital, otentikasi, dan sebagainya. Semenjak ditemukannya algoritma hash MD4 oleh Ron Rivest, telah banyak algoritma-algoritma hash yang lain yang telah dibentuk berdasarkan prinsip-prinsip dalam algoritma ini. Salah satunya adalah algoritma RIPEMD-128. RIPEMD-128 adalah fungsi hash berulang yang beroperasi pada kata-kata 32-bit. Dengan menggunakan fungsi hash maka dapat dibangkitkan identitas dari file pdf. Jika file pdf tersebut sama maka akan menghasilkan nilai hash yang sama pula. Hal ini akan memudahkan untuk mengelompokkan dokumen pdf yang sama sehingga akan mempercepat proses penghapusan file pdf yang sama. Dengan aplikasi pdf file scanner maka akan dicari file pdf ke semua folder dan akan mengelompokkan file pdf berdasarkan nilai hash yang sama. Sehingga akan memudahkan pengguna untuk menghapus file pdf yang sama.
\end{abstract}

Kata Kunci: Algoritma RIPEMD-128; Aplikasi PDF Scanner

\begin{abstract}
The development of the digital world era continues to grow and is increasing. Many industries have switched to digital technology such as photos, videos, music, and so on. Of course, this change brings many benefits in terms of speed and data access. Ease of accessing the internet also has a major impact on human life. The ease of accessing documents online is very helpful if you want to find and download pdf documents online. With this convenience, many of the same pdf files are downloaded more than once. This will definitely burden the storage space. To distinguish one pdf file from another, it is done by viewing and reading the contents of the pdf file. This is very inconvenient and time consuming. To overcome this, we need a practical way that can be used to search for the same pdf document so that it can delete duplicate pdf files. One way that can be used to overcome this problem is to use a hash function. The hash function in cryptography is a very important tool in various cryptographic applications, for example in digital signature formation, authentication, and so on. Since the discovery of the MD4 hash algorithm by Ron Rivest, many other hash algorithms have been developed based on the principles of this algorithm. One of them is the RIPEMD-128 algorithm. RIPEMD-128 is an iterative hash function that operates on 32-bit words. By using a hash function, the identity of the pdf file can be generated. If the pdf files are the same it will produce the same hash value as well. This will make it easier to group the same pdf documents so that it will speed up the process of deleting the same pdf files. With the pdf file scanner application, pdf files will be searched for all folders and will group pdf files based on the same hash value. So that it will be easier for users to delete the same pdf file.
\end{abstract}

Keywords: RIPEMD-128 Algorithm; PDF Scanner Application

\section{PENDAHULUAN}

Perkembangan jaringan internet yang semakin pesat membuat perubahan yang sangat signifikan di bidang jaringan. Begitu juga dengan referensi-referensi yang dalam bentuk buku kini sudah beralih menjadi bentuk digital. Banyak sekali buku-buku dalam bentuk digital yang biasa disebut dengan e-book disimpan menggunakan format pdf. Format pdf merupakan format standar untuk pengiriman dokumen serta di dukung oleh mayoritas sistem operasi sehingga file pdf ini bisa dibuka di berbagai sistem operasi dari berbagai platform.

Dalam ilmu kriptografi terdapat fungsi hash yang biasa digunakan untuk membangkitkan sidik jari atau fingerprint serta sering juga digunakan untuk membangkitkan tanda tangan digital (digital signature). Fungsi hash akan menghasilkan panjang nilai hash yang sama walaupun memiliki panjang input yang berbeda-beda. Hal inilah yang membuat fungsi hash di dalam kriptografi dapat digunakan untuk membangkitkan identitas dari sebuah file pdf. Dalam ilmu kriptografi banyak terdapat fungsi hash yang sering digunakan mulai dari fungsi hash yang memiliki tingkat kompleksitas yang rendah sampai fungsi hash yang memiliki tingkat kompleksitas yang tinggi.

Dalam fungsi hash terdapat dua varian dari algoritma RIPEMD yaitu dengan panjang nilai hash 128 bit dan 160 bit. Pemilihan algoritma RIPEMD-128 dikarenakan algoritma RIPEMD-128 memiliki performa yang lebih cepat jika dibandingkan dengan RIPEMD-160. Hal ini tentunya sangat berpengaruh mengingat jumlah file pdf yang akan di bangkitkan identitasnya cukup banyak, sehingga waktu proses sangat berperan penting dalam hal ini. 
Dengan dukungan dari file pdf yang sudah menjadi standar pengiriman dokumen banyak sekali file-file yang berupa referensi-referensi diunggah ke internet dalam bentuk pdf, sehingga dapat dengan mudah file pdf tersebut diakses oleh orang yang membutuhkan.

Masalah tidak jarang juga file pdf yang sama di-download lebih dari satu kali dan tersimpan di sebuah media penyimpanan. Hal ini tentunya kurang efisien karena ruang penyimpanan terpakai oleh dua file pdf yang sama. Kesulitan yang dihadapi adalah ketika file pdf yang sama tersebut disimpan dengan nama yang berbeda, tentunya user harus membuka dan membaca isi dari file pdf tersebut dan membandingkan isinya dengan isi dari file pdf yang lain. Hal ini tentunya sangat menyulitkan user untuk mengetahui apakah file pdf tersebut duplikat atau tidak.

Untuk mengatasi masalah tersebut salah satu solusi yang dapat digunakan adalah dengan memberikan identitas bagi setiap file pdf, di mana jika identitas dari file pdf itu sama menandakan bahwa isi dari file pdf tersebut adalah sama juga, dalam kata lain file pdf tersebut duplikat. Untuk dapat menghasilkan identitas dari sebuah file pdf dibutuhkan cara yang dapat mengakomodasi bahwa tidak akan pernah terjadi dua buah file pdf yang berbeda tetapi memiliki identitas yang sama. Hal ini dikarenakan identitas harus bersifat unik dan tidak boleh sama dengan yang lainnya jika file pdf tersebut berbeda.

Pada penelitian sebelumnya dilakukan oleh Frank Landelle dan Thomas Peyrin dari Nanyang Technonogical University, Singapura yang di publikasikan dalam seminar EUROCRYPT tahun 2013 dengan judul Cryptanalysis of Full RIPEMD-128 menyimpulkan bahwa serangan Collision di dilakukan pada proses kompresi dari algoritma RIPEMD-128 memungkinkan algoritma RIPEMD-128 ini memiliki nilai hash yang sama dengan input yang berbeda, tetapi disisi lain algoritma RIPEMD-128 memiliki performa yang lebih cepat jika dibandingkan dengan RIPEMD-160 [1].

\section{METODOLOGI PENELITIAN}

\subsection{Kriptografi}

Perubahan besar yang mempengaruhi keamanan adalah pengenalan sistem terdistribusi dan penggunaan jaringan dan fasilitas komunikasi untuk membawa data antara pengguna terminal dan komputer dan antara komputer dan komputer. Tindakan keamanan jaringan diperlukan untuk melindungi data selama transmisi. Tindakan tersebut dinamakan kriptografi [1][2].

\subsection{Fungsi Hash}

Fungsi Hash merupakan sebuah algoritma yang mengubah text atau message menjadi sederetan karakter acak yang memiliki jumlah karakter yang sama. Hash juga termasuk salah satu bentuk teknik kriptografi dan dikategorikan sebagai kriptografi tanpa key (unkeyed cryptosystem). Selain itu hash memiliki nama lain yang juga dikenal luas yaitu "one-way function" [3].

\subsection{RIPEMD-128}

Algoritma RIPEMD-128 (RACE Integrity Primitives Evaluation Massage Di gest-128), dirancang oleh Bart Preneel, Antoon Bosselaers dan Hans Dobbertin pada tahun 1996, merupakan fungsi hash kriptografi yang cepat yang dibuat untuk diimplementasikan pada software yang dijalankan pada mesin berarsitektur 32-bit. RIPEMD128 adalah salah satu contoh algoritma hash yang sering juga disebut dengan nama fungsi pembanding, fungsi penyusutan, intisari pesan, sidik jari, message integrity check (MIC) atau pemeriksa keutuhan pesan dan manipulation detection code (MDC) atau pendeteksi penyelenggaraan kode [4].

Fungsi hash atau arah dibuat berdasarkan ide tentang fungsi penempatan. Fungsi hash adalah sebuah fungsi atau persamaan matematika yang mengambil input dengan panjang variabel (preimage) dan mengubahnya menjadi panjang yang tetap (biasanya lebih pendek), keluarannya biasa disebut nilai hash. Fungsi hash satu arah adalah sebuah fungsi hash yang berjalan hanya satu arah. apabila ingin melindungi data dari modifikasi yang tidak terdeteksi, dapat di hitung hasil fungsi hash dari data tersebut, selanjutnya dapat menghitung hasil fungsi hash lagi dan membandingkan dengan hasil yang pertama apabila berbeda maka terjadi perubahan selama pengiriman.

RIPEMD-128 adalah suatu fungsi hash kriptografi yang dirancang untuk implementasi pada perangkat lunak dengan arsitektur 32 bit. Desain utama dari fungsi hash ini ada dua proses komputasional yang berbeda dan saling idenpenden, dimana hasil dari kedua proses ini akan digabungkan pada akhir perhitungan dengan sebuah fungsi komprosi. Sesuai dengan namamya RIPEMD-128 menghasilkan 128 bit. Hal ini dimaksudkan untuk menyediakan level sekuritas yang lebih tinggi untuk 10 tahun yang akan datang. Sama halnya dengan varian MD4 lainnya, RIPEMD-128 beroperasi pada fungsi ini adalah sebagai berikut [5]:

1. Rotasi kiri (left-rotation atau left-spin) dari pesan masukan;

2. Operasi bitwise Boolean (AND,NOT,OR,exclusive-OR);

3. Penambahan dua buah string sepanjang module 2 pada nilai hash.

Dibawah ini adalah deskripsi langkah-langkah proses perhitungan nilai hash pada algoritma RIPEMD-128:

1. Definisi fungsi, permutasi dan inisialisasi buffer 
Sebelum proses perhitungan, terlebih dahulu didefinisikan fungsi-fungsi dan permutasi yang akan digunakan pada proses kompresi. Definisi kelima fungsi tersebut adalah:
a. $\mathrm{F}(\mathrm{x}, \mathrm{y}, \mathrm{z})=[(\mathrm{x}) \operatorname{Xor}(\mathrm{y}) \operatorname{Xor}(\mathrm{z})$
b. $\mathrm{G}(\mathrm{x}, \mathrm{y}, \mathrm{z})=[(\mathrm{x})$ And $(\mathrm{y})$ or $[(\operatorname{not}(\mathrm{x}))$ And $(\mathrm{z})]$
c. $\mathrm{H}(\mathrm{x}, \mathrm{y}, \mathrm{z})=[(\mathrm{x})$ or $(\operatorname{not}(\mathrm{y}))]$ Xor $(\mathrm{z}))]$
d. $I(x, y, z)=[[(x) \operatorname{And}(z)]$ or $[(y)$ And $(\operatorname{not}(\mathrm{z}))]]$
e. $J(x, y, z)=[(x)$ Xor $[(y)$ or $(\operatorname{not}(\mathrm{z}))]]$

Dimana urutan penggunaan fungsi-fungsi tersebut pada masing-masing rantai seperti terlihat pada

Tabel 1. Urutan Fungsi Round Pada Fungsi Kompresi Algoritma RIPEMD-128.

\begin{tabular}{llllll}
\hline \multirow{2}{*}{ Line } & \multicolumn{5}{c}{ Round } \\
\cline { 2 - 6 } & $\mathbf{1}$ & $\mathbf{2}$ & $\mathbf{3}$ & $\mathbf{4}$ & $\mathbf{5}$ \\
\hline Left & F1 & F2 & F3 & F4 & F5 \\
Right & F1 & F2 & F3 & F4 & F5 \\
\hline
\end{tabular}

Sedangkan permutasi yang digunakan untuk menentukan urutan word seperti terlihat pada tabel 2.

Tabel 2. Urutan pengacakan word

\begin{tabular}{lccccc}
\hline \multirow{2}{*}{ Line } & \multicolumn{5}{c}{ Round } \\
\cline { 2 - 6 } & $\mathbf{1}$ & $\mathbf{2}$ & $\mathbf{3}$ & $\mathbf{4}$ & $\mathbf{5}$ \\
\hline Left & $\mathrm{Id}$ & $\mathrm{P}$ & $p^{2}$ & $p^{3}$ & $p^{4}$ \\
Right & $\pi$ & $\mathrm{P} \pi$ & $p^{2} \pi$ & $p^{3} \pi$ & $p^{4} \pi$ \\
\hline
\end{tabular}

Dimana $=[(9 * \mathrm{Id})+5]$ mod 16. Kemudian disiapkan juga suatu vektor awal, yaitu buffer $\left(\mathrm{H}_{0}, \mathrm{H}_{1}, \mathrm{H}_{2}, \mathrm{H}_{3}, \mathrm{H}_{4}\right)$, yang masing-masing nilainya dalam notasi heksa-desimal [6].

$\mathrm{H}_{0}: 67452301_{\mathrm{X}}$

$\mathrm{H}_{1}:$ EFCDAB89

$\mathrm{H}_{2}:$ : $88 \mathrm{BADCFE} \mathrm{X}_{\mathrm{X}}$

$\mathrm{H}_{3}: 10325476 \mathrm{x}$

$\mathrm{H}_{4}$ : C3D2EIFOX;

\section{HASIL DAN PEMBAHASAN}

Permasalahan yang dibahas pada penelitian ini terkait dengan pencarian file $p d f$ pada suatu media penyimpanan. File $p d f$ merupakan portable document format, karena bersifat portabel maka file ini banyak di dukung oleh berbagai macam aplikasi untuk menampilkannya. Dengan kemudahan ini maka banyak sekali dokumen di buat dalam bentuk $p d f$ sehingga mudah untuk di bagikan. Akan tetapi akan sangat merugikan jika terdapat beberapa file $p d f$ yang sama atau duplikat dalam sebuah media penyimpanan.

Untuk dapat membedakan file $p d f$ yang satu dengan yang lainnya maka pengguna harus melihat isi dari file $p d f$ tersebut, sehingga jika terdapat file $p d f$ yang sama pengguna dapat menghapusnya dan menyisakan hanya satu file saja. Tetapi hal ini menjadi tidak mungkin untuk dilakukan jika file pdf tersebut terdiri dari banyak halaman dan di media penyimpanan tersebut terdiri dari banyak file $p d f$. Untuk itu dibutuhkan identitas dari setiap file $p d f$, di mana file pdf tersebut merupakan hasil representasi dari isi file $p d f$. Sehingga jika terdapat lebih dari satu file $p d f$ yang memiliki nilai identitas yang sama, maka dapat dipastikan bahwa file pdf tersebut adalah ganda atau duplikat, dan pengguna dapat menghapus file tersebut sehingga hanya menyisakan satu file pdf saja.

Pada penelitian ini algoritma yang digunakan untuk membangkitkan identitas dari file $p d f$ adalah algoritma RIPEMD-128 yang di terapkan pada aplikasi duplicate $p d f$ scanner. Langkah pertama ketika akan melakukan pencarian file $p d f$ yang ganda atau duplikat adalah dengan memilih lokasi penyimpanan yang akan di lakukan pencarian file $p d f$, setelah file $p d f$ di temukan maka akan di bangkitkan identitas dari setiap file $p d t$ tersebut berupa nilai hash yang digunakan untuk mengurutkan file $p d f$ tersebut, sehingga file $p d f$ yang memiliki identitas yang sama akan diletakkan berdekatan sehingga memudahkan pengguna untuk menghapus file pdf yang ganda atau duplikat.

\subsection{Penerapan Algoritma RIPEMD-128}

Untuk menjelaskan langkah penerapan algoritma RIPEMD-128 pada aplikasi duplicate pdf scanner dengan melakukan perhitungan secara manual. Sebagai contoh pada penelitian ini menggunakan file dengan nama RIPEMD-128 berekstensi $p d f$. Ukuran dari file pdf yang digunakan pada contoh kasus adalah $311 \mathrm{~KB}$, namun untuk menyederhanakan perhitungan maka file $p d f$ tersebut tidak di hitung secara keseluruhan, tetapi hanya di ambil sampel dari file $p d f$ tersebut. Untuk melihat nilai file $p d f$ tersebut dalam bentuk heksadesimal maka pada penelitian ini menggunakan alat bantu aplikasi binary viewer. 


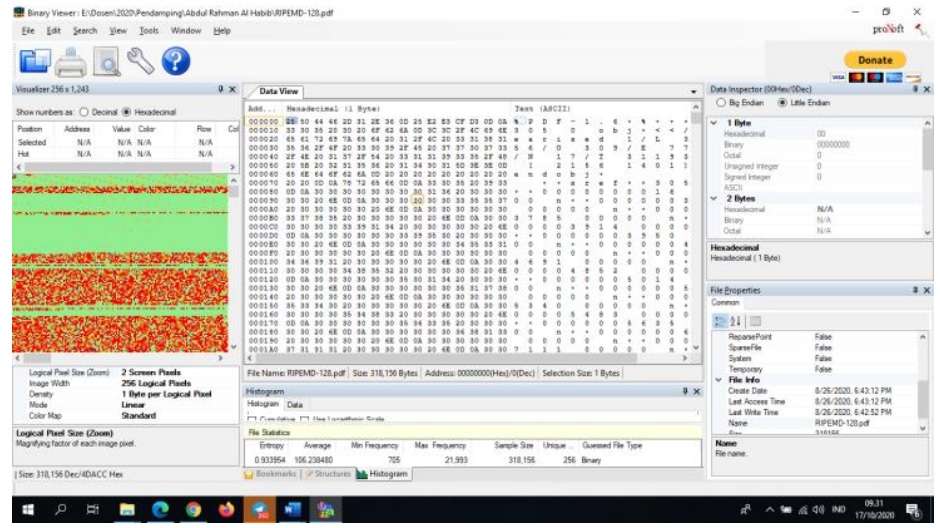

Gambar 1. Nilai Heksadesimal File Pdf

Pada gambar $1 \mathrm{di}$ atas dapat dilihat nilai heksadesimal dari file $p d f$ yang digunakan sebagai sampel. Sampel yang digunakan dalam contoh kasus ini diambil pada address 0000 sebanyak 12 bytes.

Tabel 3. Nilai Heksadesimal Sampel

\begin{tabular}{llllllllllll}
\hline M0 & M1 & M2 & M3 & M4 & M5 & M6 & M7 & M8 & M9 & M10 & M11 \\
\hline 25 & 50 & 44 & 46 & $2 \mathrm{D}$ & 31 & $2 \mathrm{E}$ & 36 & $0 \mathrm{D}$ & 25 & $\mathrm{E} 2$ & $\mathrm{E} 3$ \\
\hline
\end{tabular}

1. Penambahan Padding Bit

Untuk melakukan penambahan Padding Bit maka pesan di ubah ke dalam bentuk biner. Panjang pesan yang di gunakan sebagai sampel adalah 12 bytes sehingga jika di ubah menjadi biner jumlah pesan ada 96 bit. Maka di perlukan penambahan Padding Bit dengan ketentuan sebagai berikut:

$\mathrm{L}+1+\mathrm{M}=448 \mathrm{Mod} 512$

$\mathrm{L}+1+96=448 \operatorname{Mod} 512$

$\mathrm{L}=(448-97) \operatorname{Mod} 512$

$\mathrm{L}=351$

Maka diperlukan penambahan bit 1 kemudian di ikuti oleh bit 0 sebanyak 351 bit.

Tabel 4. Penambahan Padding Bit

\begin{tabular}{llllllll}
\hline 00100101 & 01010000 & 01000100 & 01000110 & 00101101 & 00110001 & 00101110 & 00110110 \\
00001101 & 00100101 & 11100010 & 11100011 & $\mathbf{1 0 0 0 0 0 0 0}$ & $\mathbf{0 0 0 0 0 0 0 0}$ & $\mathbf{0 0 0 0 0 0 0 0}$ & $\mathbf{0 0 0 0 0 0 0 0}$ \\
$\mathbf{0 0 0 0 0 0 0 0}$ & $\mathbf{0 0 0 0 0 0 0 0}$ & $\mathbf{0 0 0 0 0 0 0 0}$ & $\mathbf{0 0 0 0 0 0 0 0}$ & $\mathbf{0 0 0 0 0 0 0 0}$ & $\mathbf{0 0 0 0 0 0 0 0}$ & $\mathbf{0 0 0 0 0 0 0 0}$ & $\mathbf{0 0 0 0 0 0 0 0}$ \\
$\mathbf{0 0 0 0 0 0 0 0}$ & $\mathbf{0 0 0 0 0 0 0 0}$ & $\mathbf{0 0 0 0 0 0 0 0}$ & $\mathbf{0 0 0 0 0 0 0 0}$ & $\mathbf{0 0 0 0 0 0 0 0}$ & $\mathbf{0 0 0 0 0 0 0 0}$ & $\mathbf{0 0 0 0 0 0 0 0}$ & $\mathbf{0 0 0 0 0 0 0 0}$ \\
$\mathbf{0 0 0 0 0 0 0 0}$ & $\mathbf{0 0 0 0 0 0 0 0}$ & $\mathbf{0 0 0 0 0 0 0 0}$ & $\mathbf{0 0 0 0 0 0 0 0}$ & $\mathbf{0 0 0 0 0 0 0 0}$ & $\mathbf{0 0 0 0 0 0 0 0}$ & $\mathbf{0 0 0 0 0 0 0 0}$ & $\mathbf{0 0 0 0 0 0 0 0}$ \\
$\mathbf{0 0 0 0 0 0 0 0}$ & $\mathbf{0 0 0 0 0 0 0 0}$ & $\mathbf{0 0 0 0 0 0 0 0}$ & $\mathbf{0 0 0 0 0 0 0 0}$ & $\mathbf{0 0 0 0 0 0 0 0}$ & $\mathbf{0 0 0 0 0 0 0 0}$ & $\mathbf{0 0 0 0 0 0 0 0}$ & $\mathbf{0 0 0 0 0 0 0 0}$ \\
$\mathbf{0 0 0 0 0 0 0 0}$ & $\mathbf{0 0 0 0 0 0 0 0}$ & $\mathbf{0 0 0 0 0 0 0 0}$ & $\mathbf{0 0 0 0 0 0 0 0}$ & $\mathbf{0 0 0 0 0 0 0 0}$ & $\mathbf{0 0 0 0 0 0 0 0}$ & $\mathbf{0 0 0 0 0 0 0 0}$ & $\mathbf{0 0 0 0 0 0 0 0}$ \\
\hline
\end{tabular}

2. Penambahan Panjang Pesan

Langkah kedua, adalah proses penambahan 64 bit nilai yang menyatakan panjang pesan semula. Jika panjang pesan lebih besar dari $2^{64}$ maka yang diambil adalah panjangnya dengan modulo $2^{64}$. Dengan kata lain, jika panjang pesan semula adalah $\mathrm{K}$ bit, maka 64 bit yang ditambahkan menyatakan $\mathrm{K}$ modulo $2^{32}$, proses ini dapat dinamakan low-order word. Setelah ditambah dengan 64 bit, panjang pesan menjadi 512 bit. Panjang data yang digunakan adalah 96 bit sehingga jika di ubah ke dalam bentuk biner maka hasilnya adalah 01100000 . Untuk lebih jelasnya dapat di lihat pada tabel 5. berikut ini.

Tabel 5. Penambahan Panjang Pesan

\begin{tabular}{llllllll}
\hline 00100101 & 01010000 & 01000100 & 01000110 & 00101101 & 00110001 & 00101110 & 00110110 \\
00001101 & 00100101 & 11100010 & 11100011 & 10000000 & 00000000 & 00000000 & 00000000 \\
00000000 & 00000000 & 00000000 & 00000000 & 00000000 & 00000000 & 00000000 & 00000000 \\
00000000 & 00000000 & 00000000 & 00000000 & 00000000 & 00000000 & 00000000 & 00000000 \\
00000000 & 00000000 & 00000000 & 00000000 & 00000000 & 00000000 & 00000000 & 00000000 \\
00000000 & 00000000 & 00000000 & 00000000 & 00000000 & 00000000 & 00000000 & 00000000 \\
00000000 & 00000000 & 00000000 & 00000000 & 00000000 & 00000000 & 00000000 & 00000000 \\
$\mathbf{0 0 0 0 0 0 0 0}$ & $\mathbf{0 0 0 0 0 0 0 0}$ & $\mathbf{0 0 0 0 0 0 0 0}$ & $\mathbf{0 0 0 0 0 0 0 0}$ & $\mathbf{0 0 0 0 0 0 0 0}$ & $\mathbf{0 0 0 0 0 0 0 0}$ & $\mathbf{0 0 0 0 0 0 0 0}$ & $\mathbf{0 1 1 0 0 0 0 0}$ \\
\hline
\end{tabular}


Journal of Computer System and Informatics (JoSYC)

Volume 3, No. 1, November 2021, Page 16-25

ISSN 2714-8912 (media online)

ISSN 2714-7150 (media cetak)

DOI 10.47065/josyc.v3i1.822

3. Inisialisasi

Variabel input sepanjang 128 bit di bagi menjadi 4 word masing-masing berukuran 32 bit yang digunakan untuk menginisialisasi cabang kiri dan cabang kanan.

Tabel 6. Inisialisasi Cabang Kiri dan Cabang Kanan

\begin{tabular}{lllll} 
Kiri & $\mathrm{X}_{-3}=67452301$ & $\mathrm{X}_{-2}=$ EFCDAB89 & $\mathrm{X}_{-1}=$ 98BADCFE & $\mathrm{X}_{0}=10325476$ \\
Kanan & $\mathrm{Y}_{-3}=67452301$ & $\mathrm{Y}_{-2}=$ EFCDAB89 & $\mathrm{Y}_{-1}=$ 98BADCFE & $\mathrm{Y}_{0}=10325476$ \\
\hline
\end{tabular}

4. Ekspansi Pesan

Blok pesan masukkan 512 bit di bagi menjadi 16 word dan masing-masing berukuran 32 bit dapat dilihat pada tabel 4 Setiap word $\mathrm{M}_{\mathrm{i}}$ akan digunakan sekali dalam setiap putaran dalam urutan yang ditentukan untuk setiap cabang. Pada tabel 5 dan 6 berikut ini adalah tabel permutasi word untuk ekspansi pesan.

Tabel 7. Pesan Dalam 16 Word

\begin{tabular}{|c|c|c|c|c|c|c|}
\hline M0 & $=$ & 00100101 & 01010000 & 01000100 & 01000110 & $=25504446$ \\
\hline M1 & $=$ & 00101101 & 00110001 & 00101110 & 00110110 & $=2 \mathrm{D} 312 \mathrm{E} 36$ \\
\hline M2 & $=$ & 00001101 & 00100101 & 11100010 & 11100011 & $=0 \mathrm{D} 25 \mathrm{E} 2 \mathrm{E} 3$ \\
\hline M3 & $=$ & 10000000 & 00000000 & 00000000 & 00000000 & $=80000000$ \\
\hline M4 & $=$ & 00000000 & 00000000 & 00000000 & 00000000 & $=00000000$ \\
\hline M5 & $=$ & 00000000 & 00000000 & 00000000 & 00000000 & $=00000000$ \\
\hline M6 & $=$ & 00000000 & 00000000 & 00000000 & 00000000 & $=00000000$ \\
\hline M7 & $=$ & 00000000 & 00000000 & 00000000 & 00000000 & $=00000000$ \\
\hline M8 & $=$ & 00000000 & 00000000 & 00000000 & 00000000 & $=00000000$ \\
\hline M9 & $=$ & 00000000 & 00000000 & 00000000 & 00000000 & $=00000000$ \\
\hline M10 & $=$ & 00000000 & 00000000 & 00000000 & 00000000 & $=00000000$ \\
\hline M11 & $=$ & 00000000 & 00000000 & 00000000 & 00000000 & $=00000000$ \\
\hline M12 & $=$ & 00000000 & 00000000 & 00000000 & 00000000 & 00000000 \\
\hline M13 & $=$ & 00000000 & 00000000 & 00000000 & 00000000 & 00000000 \\
\hline M14 & $=$ & 00000000 & 00000000 & 00000000 & 00000000 & $=00000000$ \\
\hline M15 & $=$ & 00000000 & 00000000 & 00000000 & 01100000 & $=00000060$ \\
\hline
\end{tabular}

Tabel 8. Permutasi Word Ekspansi Pesan Cabang Kiri

\begin{tabular}{|c|c|c|c|c|c|c|c|c|c|c|c|c|c|c|c|c|}
\hline \multirow{2}{*}{ Round J } & \multicolumn{16}{|c|}{$\pi_{j}^{l}(k)$} \\
\hline & $\mathbf{0}$ & 1 & 2 & 3 & 4 & 5 & 6 & 7 & 8 & 9 & 10 & 11 & 12 & 13 & 14 & 15 \\
\hline $\mathbf{0}$ & 0 & 1 & 2 & 3 & 4 & 5 & 6 & 7 & 8 & 9 & 10 & 11 & 12 & 13 & 14 & 15 \\
\hline 1 & 7 & 4 & 13 & 1 & 10 & 6 & 15 & 3 & 12 & 0 & 9 & 5 & 2 & 14 & 11 & 8 \\
\hline 2 & 3 & 10 & 14 & 4 & 9 & 15 & 8 & 1 & 2 & 7 & 0 & 6 & 13 & 11 & 5 & 12 \\
\hline 3 & 1 & 9 & 11 & 10 & 0 & 8 & 12 & 4 & 13 & 3 & 7 & 15 & 14 & 5 & 6 & 2 \\
\hline
\end{tabular}

Tabel 9. Permutasi Word Ekspansi Pesan Cabang Kanan

\begin{tabular}{|c|c|c|c|c|c|c|c|c|c|c|c|c|c|c|c|c|}
\hline \multirow{2}{*}{ Round $\mathbf{J}$} & \multicolumn{16}{|c|}{$\pi_{j}^{r}(k)$} \\
\hline & $\mathbf{0}$ & 1 & 2 & 3 & 4 & 5 & 6 & 7 & 8 & 9 & 10 & 11 & 12 & 13 & 14 & 15 \\
\hline $\mathbf{0}$ & 5 & 14 & 7 & 0 & 9 & 2 & 11 & 4 & 13 & 6 & 15 & 8 & 1 & 10 & 3 & 12 \\
\hline 1 & 6 & 11 & 3 & 7 & 0 & 13 & 5 & 10 & 14 & 15 & 8 & 12 & 4 & 9 & 1 & 2 \\
\hline 2 & 15 & 5 & 1 & 3 & 7 & 14 & 6 & 9 & 11 & 8 & 12 & 2 & 10 & 0 & 4 & 13 \\
\hline 3 & 8 & 6 & 4 & 1 & 3 & 11 & 15 & 0 & 5 & 12 & 2 & 13 & 9 & 7 & 10 & 14 \\
\hline
\end{tabular}

Untuk melakukan ekspansi pesan maka di kerjakan dengan menggunakan persamaan:

$W_{j}^{l} 16+k=M \pi_{j}^{l}(k)$ dan $W_{j}^{r} 16+k=M \pi_{j}^{r}(k)$

Di mana $0 \leq \mathrm{j} \leq 3$ dan $0 \leq \mathrm{k} \leq 15$

Ekspansi pesan dapat dilihat pada tabel berikut ini:

Tabel 10. Ekspansi Pesan

\begin{tabular}{rcccccc}
\hline $\mathbf{i}$ & $\mathbf{j}$ & $\mathbf{k}$ & $\boldsymbol{W}_{\boldsymbol{j}}^{\boldsymbol{l}} \mathbf{1 6}+\boldsymbol{k}$ & $\boldsymbol{M} \boldsymbol{\pi}_{\boldsymbol{j}}^{\boldsymbol{l}}(\boldsymbol{k})$ & $\boldsymbol{W}_{\boldsymbol{j}}^{r} \mathbf{1 6}+\boldsymbol{k}$ & $\boldsymbol{M} \boldsymbol{\pi}_{\boldsymbol{j}}^{\boldsymbol{r}}(\boldsymbol{k})$ \\
\hline 0 & 0 & 0 & $W_{0}^{l} 16$ & 25504446 & $W_{0}^{r} 16$ & 00000000 \\
1 & 0 & 1 & $W_{0}^{l} 17$ & $2 \mathrm{D} 312 \mathrm{E} 36$ & $W_{0}^{r} 17$ & 00000000 \\
2 & 0 & 2 & $W_{0}^{l} 18$ & $0 \mathrm{D} 25 \mathrm{E} 2 \mathrm{E} 3$ & $W_{0}^{r} 18$ & 00000000 \\
3 & 0 & 3 & $W_{0}^{l} 19$ & 80000000 & $W_{0}^{l} 19$ & 25504446 \\
\hline
\end{tabular}


Journal of Computer System and Informatics (JoSYC)

Volume 3, No. 1, November 2021, Page 16-25

ISSN 2714-8912 (media online)

ISSN 2714-7150 (media cetak)

DOI 10.47065/josyc.v3i1.822

\begin{tabular}{|c|c|c|c|c|c|c|}
\hline $\mathbf{i}$ & $\mathbf{j}$ & $\mathbf{k}$ & $W_{j}^{l} 16+k$ & $M \pi_{j}^{l}(k)$ & $W_{j}^{r} 16+k$ & $M \pi_{j}^{r}(k)$ \\
\hline 4 & 0 & 4 & $W_{0}^{l} 20$ & 00000000 & $W_{0}^{l} 20$ & 00000000 \\
\hline 5 & 0 & 5 & $W_{0}^{l} 21$ & 00000000 & $W_{0}^{l} 21$ & 0D25E2E3 \\
\hline 6 & 0 & 6 & $W_{0}^{l} 22$ & 00000000 & $W_{0}^{l} 22$ & 00000000 \\
\hline 7 & 0 & 7 & $W_{0}^{l} 23$ & 00000000 & $W_{0}^{l} 23$ & 00000000 \\
\hline 8 & 0 & 8 & $W_{0}^{l} 24$ & 00000000 & $W_{0}^{l} 24$ & 00000000 \\
\hline 9 & 0 & 9 & $W_{0}^{l} 25$ & 00000000 & $W_{0}^{l} 25$ & 00000000 \\
\hline 10 & 0 & 10 & $W_{0}^{l} 26$ & 00000000 & $W_{0}^{l} 26$ & 00000060 \\
\hline 11 & 0 & 11 & $W_{0}^{l} 27$ & 00000000 & $W_{0}^{l} 27$ & 00000000 \\
\hline 12 & 0 & 12 & $W_{0}^{l} 28$ & 00000000 & $W_{0}^{l} 28$ & 2D312E36 \\
\hline 13 & 0 & 13 & $W_{0}^{l} 29$ & 00000000 & $W_{0}^{l} 29$ & 00000000 \\
\hline 14 & 0 & 14 & $W_{0}^{l} 30$ & 00000000 & $W_{0}^{l} 30$ & 80000000 \\
\hline 15 & 0 & 15 & $W_{0}^{l} 31$ & 00000060 & $W_{0}^{l} 31$ & 00000000 \\
\hline 16 & 1 & 0 & $W_{1}^{l} 16$ & 00000000 & $W_{1}^{l} 16$ & 00000000 \\
\hline 17 & 1 & 1 & $W_{1}^{l} 17$ & 00000000 & $W_{1}^{l} 17$ & 00000000 \\
\hline 18 & 1 & 2 & $W_{1}^{l} 18$ & 00000000 & $W_{1}^{l} 18$ & 80000000 \\
\hline 19 & 1 & 3 & $W_{1}^{l} 19$ & 2D312E36 & $W_{1}^{l} 19$ & 00000000 \\
\hline 20 & 1 & 4 & $W_{1}^{l} 20$ & 00000000 & $W_{1}^{l} 20$ & 25504446 \\
\hline 21 & 1 & 5 & $W_{1}^{l} 21$ & 00000000 & $W_{1}^{l} 21$ & 00000000 \\
\hline 22 & 1 & 6 & $W_{1}^{l} 22$ & 00000060 & $W_{1}^{l} 22$ & 00000000 \\
\hline 23 & 1 & 7 & $W_{1}^{l} 23$ & 80000000 & $W_{1}^{l} 23$ & 00000000 \\
\hline 24 & 1 & 8 & $W_{1}^{l} 24$ & 00000000 & $W_{1}^{l} 24$ & 00000000 \\
\hline 25 & 1 & 9 & $W_{1}^{l} 25$ & 25504446 & $W_{1}^{l} 25$ & 00000060 \\
\hline 26 & 1 & 10 & $W_{1}^{l} 26$ & 00000000 & $W_{1}^{l} 26$ & 00000000 \\
\hline 27 & 1 & 11 & $W_{1}^{l} 27$ & 00000000 & $W_{1}^{l} 27$ & 00000000 \\
\hline 28 & 1 & 12 & $W_{1}^{l} 28$ & 0D25E2E3 & $W_{1}^{l} 28$ & 00000000 \\
\hline 29 & 1 & 13 & $W_{1}^{l} 29$ & 00000000 & $W_{1}^{l} 29$ & 00000000 \\
\hline 30 & 1 & 14 & $W_{1}^{l} 30$ & 00000000 & $W_{1}^{l} 30$ & 2D312E36 \\
\hline 31 & 1 & 15 & $W_{1}^{l} 31$ & 00000000 & $W_{1}^{l} 31$ & OD25E2E3 \\
\hline 32 & 2 & 0 & $W_{2}^{l} 16$ & 80000000 & $W_{2}^{l} 16$ & 00000060 \\
\hline 33 & 2 & 1 & $W_{2}^{l} 17$ & 00000000 & $W_{2}^{l} 17$ & 00000000 \\
\hline 34 & 2 & 2 & $W_{2}^{l} 18$ & 00000000 & $W_{2}^{l} 18$ & 2D312E36 \\
\hline 35 & 2 & 3 & $W_{2}^{l} 19$ & 00000000 & $W_{2}^{l} 19$ & 80000000 \\
\hline 36 & 2 & 4 & $W_{2}^{l} 20$ & 00000000 & $W_{2}^{l} 20$ & 00000000 \\
\hline 37 & 2 & 5 & $W_{2}^{l} 21$ & 00000060 & $W_{2}^{l} 21$ & 00000000 \\
\hline 38 & 2 & 6 & $W_{2}^{l} 22$ & 00000000 & $W_{2}^{l} 22$ & 00000000 \\
\hline 39 & 2 & 7 & $W_{2}^{l} 23$ & 2D312E36 & $W_{2}^{l} 23$ & 00000000 \\
\hline 40 & 2 & 8 & $W_{2}^{l} 24$ & 0D25E2E3 & $W_{2}^{l} 24$ & 00000000 \\
\hline 41 & 2 & 9 & $W_{2}^{l} 25$ & 00000000 & $W_{2}^{l} 25$ & 00000000 \\
\hline 42 & 2 & 10 & $W_{2}^{l} 26$ & 25504446 & $W_{2}^{l} 26$ & 00000000 \\
\hline 43 & 2 & 11 & $W_{2}^{l} 27$ & 00000000 & $W_{2}^{l} 27$ & 0D25E2E3 \\
\hline 44 & 2 & 12 & $W_{2}^{l} 28$ & 00000000 & $W_{2}^{l} 28$ & 00000000 \\
\hline 45 & 2 & 13 & $W_{2}^{l} 29$ & 00000000 & $W_{2}^{l} 29$ & 25504446 \\
\hline 46 & 2 & 14 & $W_{2}^{l} 30$ & 00000000 & $W_{2}^{l} 30$ & 00000000 \\
\hline 47 & 2 & 15 & $W_{2}^{l} 31$ & 00000000 & $W_{2}^{l} 31$ & 00000000 \\
\hline 48 & 3 & 0 & $W_{3}^{l} 16$ & 2D312E36 & $W_{3}^{l} 16$ & 00000000 \\
\hline 49 & 3 & 1 & $W_{3}^{l} 17$ & 00000000 & $W_{3}^{l} 17$ & 00000000 \\
\hline 50 & 3 & 2 & $W_{3}^{l} 18$ & 00000000 & $W_{3}^{l} 18$ & 00000000 \\
\hline 51 & 3 & 3 & $W_{3}^{l} 19$ & 00000000 & $W_{3}^{l} 19$ & 2D312E36 \\
\hline 52 & 3 & 4 & $W_{3}^{l} 20$ & 25504446 & $W_{3}^{l} 20$ & 80000000 \\
\hline 53 & 3 & 5 & $W_{3}^{l} 21$ & 00000000 & $W_{3}^{l} 21$ & 00000000 \\
\hline 54 & 3 & 6 & $W_{3}^{l} 22$ & 00000000 & $W_{3}^{l} 22$ & 00000060 \\
\hline 55 & 3 & 7 & $W_{3}^{l} 23$ & 00000000 & $W_{3}^{l} 23$ & 25504446 \\
\hline 56 & 3 & 8 & $W_{3}^{l} 24$ & 00000000 & $W_{3}^{l} 24$ & 00000000 \\
\hline
\end{tabular}




\begin{tabular}{rcccccc}
\hline $\mathbf{i}$ & $\mathbf{j}$ & $\mathbf{k}$ & $\boldsymbol{W}_{\boldsymbol{j}}^{l} \mathbf{1 6}+\boldsymbol{k}$ & $\boldsymbol{M} \boldsymbol{\pi}_{\boldsymbol{j}}^{\boldsymbol{l}}(\boldsymbol{k})$ & $\boldsymbol{W}_{\boldsymbol{j}}^{\boldsymbol{r}} \mathbf{1 6}+\boldsymbol{k}$ & $\boldsymbol{M} \boldsymbol{\pi}_{\boldsymbol{j}}^{\boldsymbol{r}}(\boldsymbol{k})$ \\
\hline 57 & 3 & 9 & $W_{3}^{l} 25$ & 80000000 & $W_{3}^{l} 25$ & 00000000 \\
58 & 3 & 10 & $W_{3}^{l} 26$ & 00000000 & $W_{3}^{l} 26$ & $0 \mathrm{D} 25 \mathrm{E} 2 \mathrm{E} 3$ \\
59 & 3 & 11 & $W_{3}^{l} 27$ & 00000060 & $W_{3}^{l} 27$ & 00000000 \\
60 & 3 & 12 & $W_{3}^{l} 28$ & 00000000 & $W_{3}^{l} 28$ & 00000000 \\
61 & 3 & 13 & $W_{3}^{l} 29$ & 00000000 & $W_{3}^{l} 29$ & 00000000 \\
62 & 3 & 14 & $W_{3}^{l} 30$ & 00000000 & $W_{3}^{l} 20$ & 00000000 \\
63 & 3 & 15 & $W_{3}^{l} 31$ & $0 \mathrm{D} 25 \mathrm{E} 2 \mathrm{E} 3$ & $W_{3}^{l} 31$ & 00000000 \\
\hline
\end{tabular}

5. Step Function

Di setiap langkah ke $\mathrm{i}$, register $\mathrm{X}_{\mathrm{i}+1}$ dan $\mathrm{Y}_{\mathrm{i}+1}$ di perbaharui menggunakan fungsi $F_{j}^{l}$ dan $F_{j}^{r}$ dan tergantung pada ronde ke $\mathrm{j}$ dan langkah ke i seperti di bawah ini:

$\mathrm{X}_{\mathrm{i}+1}=\left(\mathrm{X}_{\mathrm{i}-3}+\theta_{j}^{l}\left(\mathrm{X}_{\mathrm{i}}, \mathrm{X}_{\mathrm{i}-1}, \mathrm{X}_{\mathrm{i}-2}\right)+W_{i}^{l}+K_{j}^{l}\right) \ll<s_{i}^{l}$

$\mathrm{Y}_{\mathrm{i}+1}=\left(\mathrm{Y}_{\mathrm{i}-3}+\theta_{j}^{r}\left(\mathrm{Y}_{\mathrm{i}}, \mathrm{Y}_{\mathrm{i}-1}, \mathrm{Y}_{\mathrm{i}-2}\right)+W_{i}^{r}+K_{j}^{r}\right) \ll<s_{i}^{r}$

Dimana $K_{j}^{l}$ dan $K_{j}^{r}$ konstanta 32 bit yang di definisikan setiap ronde j dan setiap cabang, $s_{i}^{l}$ dan $s_{i}^{r}$ konstanta rotasi yang di definisikan setiap langkah ke i dan setiap cabang, $\theta_{j}^{l}$ dan $\theta_{j}^{r}$ adalah 32 bit fungsi boolean yang di definisikan setiap ronde $\mathrm{j}$ dan setiap cabang. Untuk lebih jelasnya dapat di lihat pada tabel di bawah ini.

Tabel 11. Konstanta RIPEMD-128

\begin{tabular}{cllll}
\hline Round $\boldsymbol{J}$ & \multicolumn{1}{c}{$\boldsymbol{\theta}_{\boldsymbol{j}}^{\boldsymbol{l}}\left(\mathbf{X}_{\mathrm{i}}, \mathbf{X}_{\mathrm{i}-1}, \mathbf{X}_{\mathrm{i}-2}\right)$} & \multicolumn{1}{c}{$\boldsymbol{\theta}_{\boldsymbol{j}}^{\boldsymbol{r}}\left(\mathbf{Y}_{\mathrm{i}}, \mathbf{Y}_{\mathrm{i}-1}, \mathbf{Y}_{\mathrm{i}-2}\right)$} & \multicolumn{1}{c}{$\boldsymbol{K}_{\boldsymbol{j}}^{\boldsymbol{l}}$} & \multicolumn{1}{c}{$\boldsymbol{K}_{\boldsymbol{j}}$} \\
\hline $\mathbf{0}$ & $\mathrm{X}_{\mathrm{i}} \oplus \mathrm{X}_{\mathrm{i}-1} \oplus \mathrm{X}_{\mathrm{i}-2}$ & $\mathrm{Y}_{\mathrm{i}} \wedge \mathrm{Y}_{\mathrm{i}-1} \oplus \sim \mathrm{Y}_{\mathrm{i}} \wedge \mathrm{Y}_{\mathrm{i}-2}$ & 00000000 & 50A28BE6 \\
$\mathbf{1}$ & $\mathrm{X}_{\mathrm{i}} \wedge \mathrm{X}_{\mathrm{i}-1} \oplus \sim \mathrm{X}_{\mathrm{i}} \wedge \mathrm{X}_{\mathrm{i}-2}$ & $\left(\mathrm{Y}_{\mathrm{i}} \mathrm{v} \sim \mathrm{Y}_{\mathrm{i}-1}\right) \oplus \mathrm{Y}_{\mathrm{i}-2}$ & 5A827999 & 5C4DD124 \\
$\mathbf{2}$ & $\left(\mathrm{X}_{\mathrm{i}} \vee \sim \mathrm{X}_{\mathrm{i}-1}\right) \oplus \mathrm{X}_{\mathrm{i}-2}$ & $\mathrm{Y}_{\mathrm{i}} \wedge \mathrm{Y}_{\mathrm{i}-1} \oplus \sim \mathrm{Y}_{\mathrm{i}} \wedge \mathrm{Y}_{\mathrm{i}-2}$ & 6ED9EBA1 & 6D703EF3 \\
$\mathbf{3}$ & $\mathrm{X}_{\mathrm{i}} \wedge \mathrm{X}_{\mathrm{i}-1} \oplus \sim \mathrm{X}_{\mathrm{i}} \wedge \mathrm{X}_{\mathrm{i}-2}$ & $\mathrm{Y}_{\mathrm{i}} \oplus \mathrm{Y}_{\mathrm{i}-1} \oplus \mathrm{Y}_{\mathrm{i}-2}$ & 8F1BBCDC & 00000000 \\
\hline
\end{tabular}

Tabel 12. Konstanta Rotasi Kiri Cabang Kiri RIPEMD-128

\begin{tabular}{|c|c|c|c|c|c|c|c|c|c|c|c|c|c|c|c|c|}
\hline \multirow{2}{*}{ Round J } & \multicolumn{16}{|c|}{$s_{j}^{l} i$} \\
\hline & $\mathbf{0}$ & 1 & 2 & 3 & 4 & 5 & 6 & 7 & 8 & 9 & 10 & 11 & 12 & 13 & 14 & 15 \\
\hline 0 & 11 & 14 & 15 & 12 & 5 & 8 & 7 & 9 & 11 & 13 & 14 & 15 & 6 & 7 & 8 & 9 \\
\hline 1 & 7 & 6 & 8 & 13 & 11 & 9 & 7 & 15 & 7 & 12 & 15 & 9 & 11 & 7 & 13 & 12 \\
\hline 2 & 11 & 13 & 6 & 7 & 14 & 9 & 13 & 15 & 14 & 8 & 13 & 6 & 5 & 12 & 7 & 5 \\
\hline 3 & 11 & 12 & 14 & 15 & 14 & 15 & 9 & 8 & 9 & 14 & 5 & 6 & 8 & 6 & 5 & 12 \\
\hline
\end{tabular}

Tabel 13. Konstanta Rotasi Kiri Cabang Kanan RIPEMD-128

\begin{tabular}{|c|c|c|c|c|c|c|c|c|c|c|c|c|c|c|c|c|}
\hline \multirow{2}{*}{ Round J } & \multicolumn{16}{|c|}{$s_{j}^{r} i$} \\
\hline & $\mathbf{0}$ & 1 & 2 & 3 & 4 & 5 & 6 & 7 & 8 & 9 & 10 & 11 & 12 & 13 & 14 & 15 \\
\hline $\mathbf{0}$ & 8 & 9 & 9 & 11 & 13 & 15 & 15 & 5 & 7 & 7 & 8 & 11 & 14 & 14 & 12 & 6 \\
\hline 1 & 9 & 13 & 15 & 7 & 12 & 8 & 9 & 11 & 7 & 7 & 12 & 7 & 6 & 15 & 13 & 11 \\
\hline 2 & 9 & 7 & 15 & 11 & 8 & 6 & 6 & 14 & 12 & 13 & 5 & 14 & 13 & 13 & 17 & 5 \\
\hline 3 & 15 & 5 & 8 & 11 & 14 & 14 & 6 & 14 & 6 & 9 & 12 & 9 & 12 & 5 & 15 & 8 \\
\hline
\end{tabular}

Step 0 : $\mathbf{i}=\mathbf{0}, \mathbf{j}=\mathbf{0}$

$\mathrm{X}_{\mathrm{i}+1}=\left(\mathrm{X}_{\mathrm{i}-3}+\theta_{j}^{l}\left(\mathrm{X}_{\mathrm{i}}, \mathrm{X}_{\mathrm{i}-1}, \mathrm{X}_{\mathrm{i}-2}\right)+W_{i}^{l}+K_{j}^{l}\right)<<s_{i}^{l}$

$\mathrm{X}_{0+1}=\left(\mathrm{X}_{0-3}+\theta_{0}^{l}\left(\mathrm{X}_{0}, \mathrm{X}_{0-1}, \mathrm{X}_{0-2}\right)+W_{0}^{l}+K_{0}^{l}\right)<<<s_{0}^{l}$

$\mathrm{X}_{1}=\left(\mathrm{X}_{-3}+\theta_{0}^{l}\left(\mathrm{X}_{0}, \mathrm{X}_{-1}, \mathrm{X}_{-2}\right)+W_{0}^{l}+K_{0}^{l}\right)<<<s_{0}^{l}$

$\mathrm{X}_{1}=\left(67452301+\theta_{0}^{l}\left(\mathrm{X}_{0}, \mathrm{X}_{-1}, \mathrm{X}_{-2}\right)+25504446+00000000\right) \ll<11$

$\theta_{0}^{l}\left(\mathrm{X}_{0}, \mathrm{X}_{-1}, \mathrm{X}_{-2}\right)=\mathrm{X}_{\mathrm{i}} \oplus \mathrm{X}_{\mathrm{i}-1} \oplus \mathrm{X}_{\mathrm{i}-2}$

$\theta_{0}^{l}\left(\mathrm{X}_{0}, \mathrm{X}_{-1}, \mathrm{X}_{-2}\right)=\mathrm{X}_{0} \oplus \mathrm{X}_{0-1} \oplus \mathrm{X}_{0-2}$

$\theta_{0}^{l}\left(\mathrm{X}_{0}, \mathrm{X}_{-1}, \mathrm{X}_{-2}\right)=10325476 \oplus 98 \mathrm{BADCFE} \oplus \mathrm{EFCDAB} 89$

$\theta_{0}^{l}\left(\mathrm{X}_{0}, \mathrm{X}_{-1}, \mathrm{X}_{-2}\right)=67452301$

$\mathrm{X}_{1}=(67452301+67452301+25504446+00000000)<<<11$

$\mathrm{X}_{1}=(\mathrm{F} 3 \mathrm{DA} 8 \mathrm{~A} 48)<<11$

$\mathrm{X}_{1}=\mathrm{D} 452479 \mathrm{E}$

$\mathrm{Y}_{\mathrm{i}+1}=\left(\mathrm{Y}_{\mathrm{i}-3}+\theta_{j}^{r}\left(\mathrm{Y}_{\mathrm{i}}, \mathrm{Y}_{\mathrm{i}-1}, \mathrm{Y}_{\mathrm{i}-2}\right)+W_{i}^{r}+K_{j}^{r}\right) \ll<s_{i}^{r}$

$\mathrm{Y}_{0+1}=\left(\mathrm{Y}_{0-3}+\theta_{0}^{r}\left(\mathrm{Y}_{0}, \mathrm{Y}_{0-1}, \mathrm{Y}_{0-2}\right)+W_{0}^{r}+K_{0}^{r}\right) \ll<s_{0}^{r}$

$\mathrm{Y}_{1}=\left(\mathrm{Y}_{-3}+\theta_{0}^{r}\left(\mathrm{Y}_{0}, \mathrm{Y}_{-1}, \mathrm{Y}_{-2}\right)+W_{0}^{r}+K_{0}^{r}\right) \ll<s_{0}^{r}$ 


$$
\begin{aligned}
& \mathrm{Y}_{1}=\left(67452301+\theta_{0}^{r}\left(\mathrm{Y}_{0}, \mathrm{Y}_{-1}, \mathrm{Y}_{-2}\right)+00000000+50 \mathrm{~A} 28 \mathrm{BE} 6\right) \ll<< \\
& \theta_{j}^{r}\left(\mathrm{Y}_{0}, \mathrm{Y}_{0-1}, \mathrm{Y}_{0-2}\right)=\mathrm{Y}_{0} \wedge \mathrm{Y}_{0-1} \oplus \sim \mathrm{Y}_{0} \wedge \mathrm{Y}_{0-2} \\
& \theta_{j}^{r}\left(\mathrm{Y}_{0}, \mathrm{Y}_{-1}, \mathrm{Y}_{-2}\right)=\mathrm{Y}_{0} \wedge \mathrm{Y}_{-1} \oplus \sim \mathrm{Y}_{0} \wedge \mathrm{Y}_{-2} \\
& \theta_{j}^{r}\left(\mathrm{Y}_{0}, \mathrm{Y}_{-1}, \mathrm{Y}_{-2}\right)=10325476^{\wedge} 98 \mathrm{BADCFE} \oplus \sim 10325476 \wedge \text { EFCDAB89 } \\
& \theta_{j}^{r}\left(\mathrm{Y}_{0}, \mathrm{Y}_{-1}, \mathrm{Y}_{-2}\right)=10325476 \oplus \text { EFCDAB89 } \\
& \theta_{j}^{r}\left(\mathrm{Y}_{0}, \mathrm{Y}_{-1}, \mathrm{Y}_{-2}\right)=\mathrm{FFFFFFF} \\
& \mathrm{Y}_{1}=(67452301+\mathrm{FFFFFFFF}+00000000+50 \mathrm{~A} 28 \mathrm{BE} 6) \ll<<8 \\
& \mathrm{Y}_{1}=(\mathrm{B} 7 \mathrm{~B} 7 \mathrm{AEE} 6) \ll<8 \\
& \mathrm{Y}_{1}=\mathrm{E} 7 \mathrm{EEE6B} 7
\end{aligned}
$$

\section{Step $1: \mathbf{i}=\mathbf{1}, \mathbf{j}=\mathbf{0}$}

$\mathrm{X}_{\mathrm{i}+1}=\left(\mathrm{X}_{\mathrm{i}-3}+\theta_{j}^{l}\left(\mathrm{X}_{\mathrm{i}}, \mathrm{X}_{\mathrm{i}-1}, \mathrm{X}_{\mathrm{i}-2}\right)+W_{i}^{l}+K_{j}^{l}\right) \ll<s_{i}^{l}$

$\mathrm{X}_{1+1}=\left(\mathrm{X}_{1-3}+\theta_{0}^{l}\left(\mathrm{X}_{1}, \mathrm{X}_{1-1}, \mathrm{X}_{1-2}\right)+W_{1}^{l}+K_{0}^{l}\right)<<<s_{1}^{l}$

$\mathrm{X}_{2}=\left(\mathrm{X}_{-2}+\theta_{0}^{l}\left(\mathrm{X}_{1}, \mathrm{X}_{0}, \mathrm{X}_{-1}\right)+W_{1}^{l}+K_{0}^{l}\right)<<s_{1}^{l}$

$\mathrm{X}_{2}=\left(\right.$ EFCDAB $\left.89+\theta_{0}^{l}\left(\mathrm{X}_{1}, \mathrm{X}_{0}, \mathrm{X}_{-1}\right)+2 \mathrm{D} 312 \mathrm{E} 36+00000000\right)<<14$

$\theta_{0}^{l}\left(\mathrm{X}_{1}, \mathrm{X}_{0}, \mathrm{X}_{-1}\right)=\mathrm{X}_{\mathrm{i}} \oplus \mathrm{X}_{\mathrm{i}-1} \oplus \mathrm{X}_{\mathrm{i}-2}$

$\theta_{0}^{l}\left(\mathrm{X}_{1}, \mathrm{X}_{0}, \mathrm{X}_{-1}\right)=\mathrm{X}_{1} \oplus \mathrm{X}_{1-1} \oplus \mathrm{X}_{1-2}$

$\theta_{0}^{l}\left(\mathrm{X}_{1}, \mathrm{X}_{0}, \mathrm{X}_{-1}\right)=\mathrm{D} 452479 \mathrm{E} \oplus 10325476 \oplus$ 98BADCFE

$\theta_{0}^{l}\left(\mathrm{X}_{1}, \mathrm{X}_{0}, \mathrm{X}_{-1}\right)=5 \mathrm{CDACF} 16$

$\mathrm{X}_{2}=(\mathrm{EFCDAB} 89+5 \mathrm{CDACF} 16+2 \mathrm{D} 312 \mathrm{E} 36+00000000)<<<<14$

$\mathrm{X}_{2}=$ CACECC $4 \mathrm{~A} \ll<<14$

$\mathrm{X}_{2}=\mathrm{B} 312 \mathrm{~B} 2 \mathrm{~B} 3$

$$
\begin{aligned}
& \mathrm{Y}_{\mathrm{i}+1}=\left(\mathrm{Y}_{\mathrm{i}-3}+\theta_{j}^{r}\left(\mathrm{Y}_{\mathrm{i}}, \mathrm{Y}_{\mathrm{i}-1}, \mathrm{Y}_{\mathrm{i}-2}\right)+W_{i}^{r}+K_{j}^{r}\right) \ll<s_{i}^{r} \\
& \mathrm{Y}_{1+1}=\left(\mathrm{Y}_{1-3}+\theta_{0}^{r}\left(\mathrm{Y}_{1}, \mathrm{Y}_{1-1}, \mathrm{Y}_{1-2}\right)+W_{1}^{r}+K_{0}^{r}\right) \ll<s_{1}^{r} \\
& \mathrm{Y}_{2}=\left(\mathrm{Y}_{-2}+\theta_{0}^{r}\left(\mathrm{Y}_{1}, \mathrm{Y}_{0}, \mathrm{Y}_{-1}\right)+W_{1}^{r}+K_{0}^{r}\right)<<s_{1}^{r} \\
& \mathrm{Y}_{2}=\left(\text { EFCDAB89 }+\theta_{0}^{r}\left(\mathrm{Y}_{1}, \mathrm{Y}_{0}, \mathrm{Y}_{-1}\right)+00000000+50 \mathrm{~A} 28 \mathrm{BE} 6\right) \ll<9 \\
& \theta_{0}^{r}\left(\mathrm{Y}_{1}, \mathrm{Y}_{0}, \mathrm{Y}_{-1}\right)=\mathrm{Y}_{1} \wedge \mathrm{Y}_{0-0} \oplus \sim \mathrm{Y}_{1} \wedge \mathrm{Y}_{0-1} \\
& \theta_{0}^{r}\left(\mathrm{Y}_{1}, \mathrm{Y}_{0}, \mathrm{Y}_{-1}\right)=\mathrm{Y}_{1} \wedge \mathrm{Y}_{0} \oplus \sim \mathrm{Y}_{1} \wedge \mathrm{Y}_{-1} \\
& \theta_{0}^{r}\left(\mathrm{Y}_{1}, \mathrm{Y}_{0}, \mathrm{Y}_{-1}\right)=\mathrm{E} 7 \mathrm{AEE} 6 \mathrm{~B} 7 \wedge 10325476 \oplus \sim \mathrm{E} 7 \mathrm{AEE} 6 \mathrm{~B} 7 \wedge \text { 98BADCFE } \\
& \theta_{0}^{r}\left(\mathrm{Y}_{1}, \mathrm{Y}_{0}, \mathrm{Y}_{-1}\right)=224436 \oplus 18101848 \\
& \theta_{j}^{r}\left(\mathrm{Y}_{0}, \mathrm{Y}_{-1}, \mathrm{Y}_{-2}\right)=18325 \mathrm{C} 7 \mathrm{E} \\
& \mathrm{Y}_{2}=(\text { EFCDAB89 +18325C7E }+00000000+50 \text { A28BE6 })<<<9 \\
& \mathrm{Y}_{2}=(58 \mathrm{~A} 293 \mathrm{ED})<<<9 \\
& \mathrm{Y}_{2}=4527 \mathrm{DAB} 1
\end{aligned}
$$

\section{Step $2: \mathbf{i}=\mathbf{2}, \mathbf{j}=\mathbf{0}$}

$\mathrm{X}_{\mathrm{i}+1}=\left(\mathrm{X}_{\mathrm{i}-3}+\theta_{j}^{l}\left(\mathrm{X}_{\mathrm{i}}, \mathrm{X}_{\mathrm{i}-1}, \mathrm{X}_{\mathrm{i}-2}\right)+W_{i}^{l}+K_{j}^{l}\right) \ll<s_{i}^{l}$

$\mathrm{X}_{2+1}=\left(\mathrm{X}_{2-3}+\theta_{0}^{l}\left(\mathrm{X}_{2}, \mathrm{X}_{2-1}, \mathrm{X}_{2-2}\right)+W_{2}^{l}+K_{0}^{l}\right) \ll<s_{2}^{l}$

$\mathrm{X}_{3}=\left(\mathrm{X}_{-1}+\theta_{0}^{l}\left(\mathrm{X}_{2}, \mathrm{X}_{1}, \mathrm{X}_{0}\right)+W_{2}^{l}+K_{0}^{l}\right) \ll<s_{2}^{l}$

$\mathrm{X}_{3}=\left(\right.$ 98BADCFE $\left.+\theta_{0}^{l}\left(\mathrm{X}_{2}, \mathrm{X}_{1}, \mathrm{X}_{0}\right)+0 \mathrm{D} 25 \mathrm{E} 2 \mathrm{E} 3+00000000\right)<<15$

$\theta_{0}^{l}\left(\mathrm{X}_{2}, \mathrm{X}_{1}, \mathrm{X}_{0}\right)=\mathrm{X}_{\mathrm{i}} \oplus \mathrm{X}_{\mathrm{i}-1} \oplus \mathrm{X}_{\mathrm{i}-2}$

$\theta_{0}^{l}\left(\mathrm{X}_{2}, \mathrm{X}_{1}, \mathrm{X}_{0}\right)=\mathrm{X}_{2} \oplus \mathrm{X}_{2-1} \oplus \mathrm{X}_{2-2}$

$\theta_{0}^{l}\left(\mathrm{X}_{2}, \mathrm{X}_{1}, \mathrm{X}_{0}\right)=\mathrm{B} 312 \mathrm{~B} 2 \mathrm{~B} 3 \oplus \mathrm{D} 452479 \mathrm{E} \oplus 10325476$

$\theta_{0}^{l}\left(\mathrm{X}_{2}, \mathrm{X}_{1}, \mathrm{X}_{0}\right)=7778 \mathrm{AA} 51$

$\mathrm{X}_{3}=($ 98BADCFE + 5CDACF $16+$ 0D25E2E $3+00000000)<<<<15$

$\mathrm{X}_{3}=22 \mathrm{C} 6 \mathrm{DA} 4 \mathrm{~A} \quad \ll<<15$

$\mathrm{X}_{3}=6 \mathrm{D} 251163$

$$
\begin{aligned}
& \mathrm{Y}_{\mathrm{i}+1}=\left(\mathrm{Y}_{\mathrm{i}-3}+\theta_{j}^{r}\left(\mathrm{Y}_{\mathrm{i}}, \mathrm{Y}_{\mathrm{i}-1}, \mathrm{Y}_{\mathrm{i}-2}\right)+W_{i}^{r}+K_{j}^{r}\right) \ll<s_{i}^{r} \\
& \mathrm{Y}_{2+1}=\left(\mathrm{Y}_{2-3}+\theta_{0}^{r}\left(\mathrm{Y}_{2}, \mathrm{Y}_{2-1}, \mathrm{Y}_{2-2}\right)+W_{2}^{r}+K_{0}^{r}\right) \ll<<s_{2}^{r} \\
& \mathrm{Y}_{3}=\left(\mathrm{Y}_{-1}+\theta_{0}^{r}\left(\mathrm{Y}_{2}, \mathrm{Y}_{1}, \mathrm{Y}_{0}\right)+W_{2}^{r}+K_{0}^{r}\right) \ll<s_{2}^{r} \\
& \mathrm{Y}_{3}=\left(98 B A D C F E+\theta_{0}^{r}\left(\mathrm{Y}_{2}, \mathrm{Y}_{1}, \mathrm{Y}_{0}\right)+0 \mathrm{D} 25 \mathrm{E} 2 \mathrm{E} 3+50 \mathrm{~A} 28 \mathrm{BE} 6\right) \ll<9 \\
& \theta_{0}^{r}\left(\mathrm{Y}_{2}, \mathrm{Y}_{1}, \mathrm{Y}_{0}\right)=\mathrm{Y}_{2} \wedge \mathrm{Y}_{1-0} \oplus \sim \mathrm{Y}_{2} \wedge \mathrm{Y}_{0-0} \\
& \theta_{0}^{r}\left(\mathrm{Y}_{2}, \mathrm{Y}_{1}, \mathrm{Y}_{0}\right)=\mathrm{Y}_{2} \wedge \mathrm{Y}_{1} \oplus \sim \mathrm{Y}_{2} \wedge \mathrm{Y}_{0} \\
& \theta_{0}^{r}\left(\mathrm{Y}_{2}, \mathrm{Y}_{1}, \mathrm{Y}_{0}\right)=4527 \mathrm{DAB} 1^{\wedge} \mathrm{E} 7 \mathrm{AEE} 6 \mathrm{~B} 7 \oplus \sim 4527 \mathrm{DAB} 1 \wedge 10325476 \\
& \theta_{0}^{r}\left(\mathrm{Y}_{2}, \mathrm{Y}_{1}, \mathrm{Y}_{0}\right)=4526 \mathrm{C} 2 \mathrm{~B} 1 \oplus 10100446 \\
& \theta_{0}^{r}\left(\mathrm{Y}_{2}, \mathrm{Y}_{1}, \mathrm{Y}_{0}\right)=5536 \mathrm{C} 6 \mathrm{~F} 7 \\
& \mathrm{Y}_{3}=(98 \mathrm{BADCFE}+5536 \mathrm{C} 6 \mathrm{~F} 7+0 \mathrm{D} 25 \mathrm{E} 2 \mathrm{E} 3+50 \mathrm{~A} 28 \mathrm{BE} 6) \ll<<9
\end{aligned}
$$




\section{Journal of Computer System and Informatics (JoSYC)}

Volume 3, No. 1, November 2021, Page 16-25

ISSN 2714-8912 (media online)

ISSN 2714-7150 (media cetak)

DOI 10.47065/josyc.v3i1.822

$$
\begin{aligned}
& \mathrm{Y}_{3}=(3 \mathrm{E} 942 \mathrm{FDB}) \ll<9 \\
& \mathrm{Y}_{3}=285 \mathrm{FB} 67 \mathrm{D}
\end{aligned}
$$

\section{Step $3: \mathbf{i}=\mathbf{3}, \mathbf{j}=\mathbf{0}$}

$\mathrm{X}_{\mathrm{i}+1}=\left(\mathrm{X}_{\mathrm{i}-3}+\theta_{j}^{l}\left(\mathrm{X}_{\mathrm{i}}, \mathrm{X}_{\mathrm{i}-1}, \mathrm{X}_{\mathrm{i}-2}\right)+W_{i}^{l}+K_{j}^{l}\right) \ll<s_{i}^{l}$

$\mathrm{X}_{3+1}=\left(\mathrm{X}_{3-3}+\theta_{0}^{l}\left(\mathrm{X}_{3}, \mathrm{X}_{3-1}, \mathrm{X}_{3-2}\right)+W_{3}^{l}+K_{0}^{l}\right) \ll<s_{3}^{l}$

$\mathrm{X}_{4}=\left(\mathrm{X}_{0}+\theta_{0}^{l}\left(\mathrm{X}_{1}, \mathrm{X}_{2}, \mathrm{X}_{1}\right)+W_{3}^{l}+K_{0}^{l}\right)<<<s_{3}^{l}$

$\mathrm{X}_{4}=\left(10325476+\theta_{0}^{l}\left(\mathrm{X}_{1}, \mathrm{X}_{2}, \mathrm{X}_{1}\right)+80000000+00000000\right)<<12$

$\theta_{0}^{l}\left(\mathrm{X}_{1}, \mathrm{X}_{2}, \mathrm{X}_{1}\right)=\mathrm{X}_{\mathrm{i}} \oplus \mathrm{X}_{\mathrm{i}-1} \oplus \mathrm{X}_{\mathrm{i}-2}$

$\theta_{0}^{l}\left(\mathrm{X}_{1}, \mathrm{X}_{2}, \mathrm{X}_{1}\right)=\mathrm{X}_{3} \oplus \mathrm{X}_{3-1} \oplus \mathrm{X}_{3-2}$

$\theta_{0}^{l}\left(\mathrm{X}_{1}, \mathrm{X}_{2}, \mathrm{X}_{1}\right)=6 \mathrm{D} 251163 \oplus \mathrm{B} 312 \mathrm{~B} 2 \mathrm{~B} 3 \oplus \mathrm{D} 452479 \mathrm{E}$

$\theta_{0}^{l}\left(\mathrm{X}_{1}, \mathrm{X}_{2}, \mathrm{X}_{1}\right)=\mathrm{A} 65 \mathrm{E} 44 \mathrm{E}$

$\mathrm{X}_{4}=(10325476+\mathrm{A} 65 \mathrm{E} 44 \mathrm{E}+80000000+00000000)<<<12$

$\mathrm{X}_{4}=9 \mathrm{~A} 9838 \mathrm{C} 4 \ll<<<12$

$\mathrm{X}_{4}=838 \mathrm{C} 49 \mathrm{~A} 9$

$$
\begin{aligned}
& \mathrm{Y}_{\mathrm{i}+1}=\left(\mathrm{Y}_{\mathrm{i}-3}+\theta_{j}^{r}\left(\mathrm{Y}_{\mathrm{i}}, \mathrm{Y}_{\mathrm{i}-1}, \mathrm{Y}_{\mathrm{i}-2}\right)+W_{i}^{r}+K_{j}^{r}\right) \ll<s_{i}^{r} \\
& \mathrm{Y}_{3+1}=\left(\mathrm{Y}_{3-3}+\theta_{0}^{r}\left(\mathrm{Y}_{3}, \mathrm{Y}_{3-1}, \mathrm{Y}_{3-2}\right)+W_{3}^{r}+K_{0}^{r}\right) \ll<s_{3}^{r} \\
& \mathrm{Y}_{4}=\left(\mathrm{Y}_{0}+\theta_{0}^{r}\left(\mathrm{Y}_{3}, \mathrm{Y}_{2}, \mathrm{Y}_{1}\right)+W_{3}^{r}+K_{0}^{r}\right) \ll<s_{3}^{r} \\
& \mathrm{Y}_{4}=\left(10325476+\theta_{0}^{r}\left(\mathrm{Y}_{2}, \mathrm{Y}_{1}, \mathrm{Y}_{0}\right)+25504446+50 \mathrm{~A} 28 \mathrm{BE} 6\right)<<<11 \\
& \theta_{0}^{r}\left(\mathrm{Y}_{3}, \mathrm{Y}_{2}, \mathrm{Y}_{1}\right)=\mathrm{Y}_{3} \wedge \mathrm{Y}_{2-0} \oplus \sim \mathrm{Y}_{3} \wedge \mathrm{Y}_{1-0} \\
& \theta_{0}^{r}\left(\mathrm{Y}_{3}, \mathrm{Y}_{2}, \mathrm{Y}_{1}\right)=\mathrm{Y}_{3} \wedge \mathrm{Y}_{2} \oplus \sim \mathrm{Y}_{3} \wedge \mathrm{Y}_{1} \\
& \theta_{0}^{r}\left(\mathrm{Y}_{3}, \mathrm{Y}_{2}, \mathrm{Y}_{1}\right)=285 \mathrm{FB} 67 \mathrm{D} \wedge \text { 4527DAB1 } \oplus \sim 285 \mathrm{FB} 67 \mathrm{D} \wedge \text { E7AEE6B7 } \\
& \theta_{0}^{r}\left(\mathrm{Y}_{3}, \mathrm{Y}_{2}, \mathrm{Y}_{1}\right)=79231 \oplus \mathrm{C} 7 \mathrm{~A} 04082 \\
& \theta_{0}^{r}\left(\mathrm{Y}_{3}, \mathrm{Y}_{2}, \mathrm{Y}_{1}\right)=\mathrm{C} 7 \mathrm{~A} 7 \mathrm{D} 2 \mathrm{~B} 3 \\
& \mathrm{Y}_{4}=(10325476+\text { C7A7D2B3 }+25504446+50 \mathrm{~A} 28 \mathrm{BE} 6)<<<11 \\
& \mathrm{Y}_{4}=(4 \mathrm{DCCF} 755)<<11 \\
& \mathrm{Y}_{4}=67 \mathrm{BAAA} 6
\end{aligned}
$$

\section{Step $4: \mathbf{i}=\mathbf{4}, \mathbf{j}=\mathbf{0}$}

$\mathrm{X}_{\mathrm{i}+1}=\left(\mathrm{X}_{\mathrm{i}-3}+\theta_{j}^{l}\left(\mathrm{X}_{\mathrm{i}}, \mathrm{X}_{\mathrm{i}-1}, \mathrm{X}_{\mathrm{i}-2}\right)+W_{i}^{l}+K_{j}^{l}\right) \ll<s_{i}^{l}$

$\mathrm{X}_{4+1}=\left(\mathrm{X}_{4-3}+\theta_{0}^{l}\left(\mathrm{X}_{4}, \mathrm{X}_{4-1}, \mathrm{X}_{4-2}\right)+W_{4}^{l}+K_{0}^{l}\right)<<<s_{4}^{l}$

$\mathrm{X}_{5}=\left(\mathrm{X}_{1}+\theta_{0}^{l}\left(\mathrm{X}_{4}, \mathrm{X}_{3}, \mathrm{X}_{2}\right)+W_{4}^{l}+K_{0}^{l}\right) \ll<s_{4}^{l}$

$\mathrm{X}_{5}=\left(10325476+\theta_{0}^{l}\left(\mathrm{X}_{4}, \mathrm{X}_{3}, \mathrm{X}_{2}\right)+00000000+00000000\right)<<5$

$\theta_{0}^{l}\left(\mathrm{X}_{4}, \mathrm{X}_{3}, \mathrm{X}_{2}\right)=\mathrm{X}_{\mathrm{i}} \oplus \mathrm{X}_{\mathrm{i}-1} \oplus \mathrm{X}_{\mathrm{i}-2}$

$\theta_{0}^{l}\left(\mathrm{X}_{4}, \mathrm{X}_{3}, \mathrm{X}_{2}\right)=\mathrm{X}_{4} \oplus \mathrm{X}_{4-1} \oplus \mathrm{X}_{4-2}$

$\theta_{0}^{l}\left(\mathrm{X}_{4}, \mathrm{X}_{3}, \mathrm{X}_{2}\right)=838 \mathrm{C} 49 \mathrm{~A} 9 \oplus 6 \mathrm{D} 251163 \oplus \mathrm{B} 312 \mathrm{~B} 2 \mathrm{~B} 3$

$\theta_{0}^{l}\left(\mathrm{X}_{4}, \mathrm{X}_{3}, \mathrm{X}_{2}\right)=$ 5DBBEA79

$\mathrm{X}_{5}(10325476+$ 5DBBEA79 $+00000000+00000000)<<<5$

$\mathrm{X}_{5}=6 \mathrm{DEE} 3 \mathrm{EEF}<<<<5$

$\mathrm{X}_{5}=\mathrm{BDC7DDED}$

$\mathrm{Y}_{\mathrm{i}+1}=\left(\mathrm{Y}_{\mathrm{i}-3}+\theta_{j}^{r}\left(\mathrm{Y}_{\mathrm{i}}, \mathrm{Y}_{\mathrm{i}-1}, \mathrm{Y}_{\mathrm{i}-2}\right)+W_{i}^{r}+K_{j}^{r}\right) \ll<s_{i}^{r}$

$\mathrm{Y}_{4+1}=\left(\mathrm{Y}_{4-3}+\theta_{0}^{r}\left(\mathrm{Y}_{4}, \mathrm{Y}_{4-1}, \mathrm{Y}_{4-2}\right)+W_{4}^{r}+K_{0}^{r}\right) \ll<s_{4}^{r}$

$\mathrm{Y}_{5}=\left(\mathrm{Y}_{1}+\theta_{0}^{r}\left(\mathrm{Y}_{4}, \mathrm{Y}_{3}, \mathrm{Y}_{2}\right)+W_{4}^{r}+K_{0}^{r}\right) \ll<s_{4}^{r}$

$\mathrm{Y}_{5}=\left(\right.$ E7AEE6B7 $\left.+\theta_{0}^{r}\left(\mathrm{Y}_{4}, \mathrm{Y}_{3}, \mathrm{Y}_{2}\right)+00000000+50 \mathrm{~A} 28 \mathrm{BE} 6\right)<<<13$

$\theta_{0}^{r}\left(\mathrm{Y}_{4}, \mathrm{Y}_{3}, \mathrm{Y}_{2}\right)=\mathrm{Y}_{4} \wedge \mathrm{Y}_{3-0} \oplus \sim \mathrm{Y}_{4} \wedge \mathrm{Y}_{2-0}$

$\theta_{0}^{r}\left(\mathrm{Y}_{4}, \mathrm{Y}_{3}, \mathrm{Y}_{2}\right)=\mathrm{Y}_{4} \wedge \mathrm{Y}_{3} \oplus \sim \mathrm{Y}_{4} \wedge \mathrm{Y}_{2}$

$\theta_{0}^{r}\left(\mathrm{Y}_{4}, \mathrm{Y}_{3}, \mathrm{Y}_{2}\right)=10325476^{\wedge} 285 \mathrm{FB} 67 \mathrm{D} \oplus \sim 10325476^{\wedge} 4527 \mathrm{DAB} 1$

$\theta_{0}^{r}\left(\mathrm{Y}_{4}, \mathrm{Y}_{3}, \mathrm{Y}_{2}\right)=121474 \oplus 45058 \mathrm{~A} 81$

$\theta_{0}^{r}\left(\mathrm{Y}_{4}, \mathrm{Y}_{3}, \mathrm{Y}_{2}\right)=45179 \mathrm{EF} 5$

$\mathrm{Y}_{5}=($ E7AEE6B7 + 45179EF5 + 00000000+ 50A28BE6) $<<<13$

$\mathrm{Y}_{5}=(7 \mathrm{D} 691192)<<<13$

$\mathrm{Y}_{5}=22324 \mathrm{FAD}$

\section{Step $5: \mathbf{i}=\mathbf{5}, \mathbf{j}=\mathbf{0}$}

$\mathrm{X}_{\mathrm{i}+1}=\left(\mathrm{X}_{\mathrm{i}-3}+\theta_{j}^{l}\left(\mathrm{X}_{\mathrm{i}}, \mathrm{X}_{\mathrm{i}-1}, \mathrm{X}_{\mathrm{i}-2}\right)+W_{i}^{l}+K_{j}^{l}\right) \ll<s_{i}^{l}$

$\mathrm{X}_{5+1}=\left(\mathrm{X}_{5-3}+\theta_{0}^{l}\left(\mathrm{X}_{5}, \mathrm{X}_{5-1}, \mathrm{X}_{5-2}\right)+W_{5}^{l}+K_{0}^{l}\right) \ll<s_{5}^{l}$

$\mathrm{X}_{6}=\left(\mathrm{X}_{2}+\theta_{0}^{l}\left(\mathrm{X}_{5}, \mathrm{X}_{4}, \mathrm{X}_{3}\right)+W_{5}^{l}+K_{0}^{l}\right) \ll<s_{5}^{l}$ 


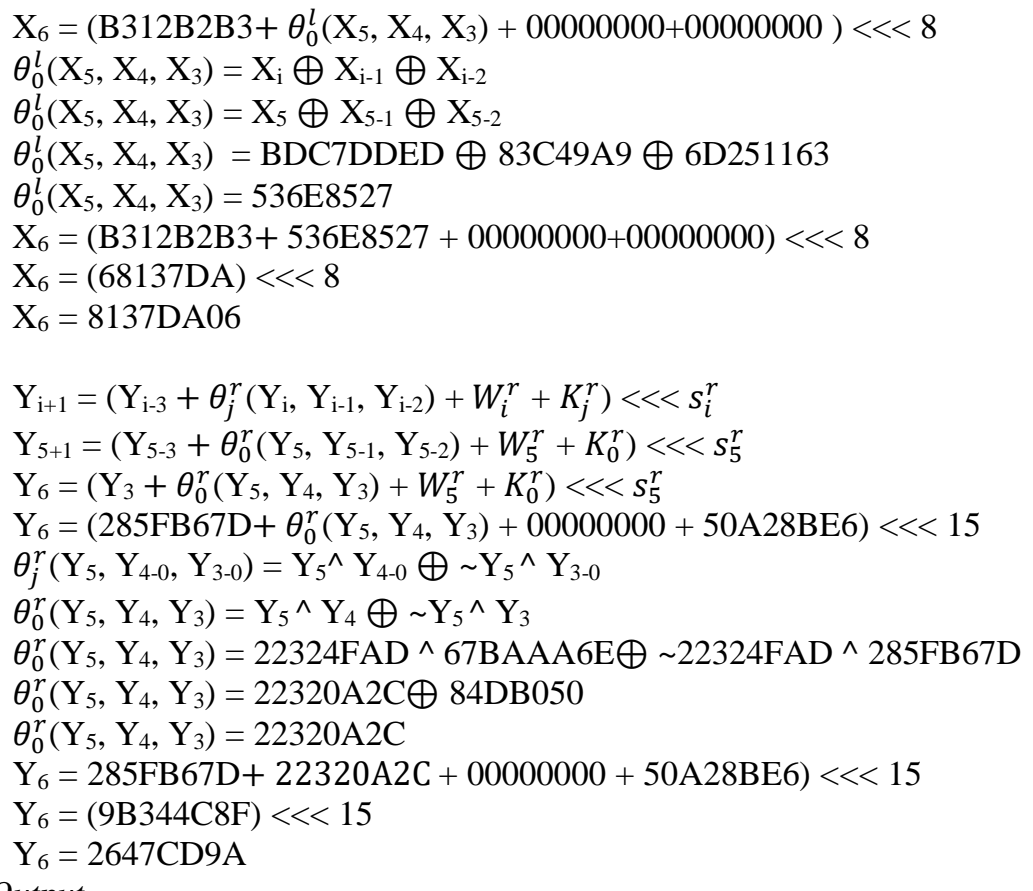

6. Output

Keluaran nilai hash dari algoritma RIPEMD-128 dihasilkan dari 64 langkah di kedua cabangnya. 4 word berukuran 32 bit di dapatkan dari perhitungan berikut:

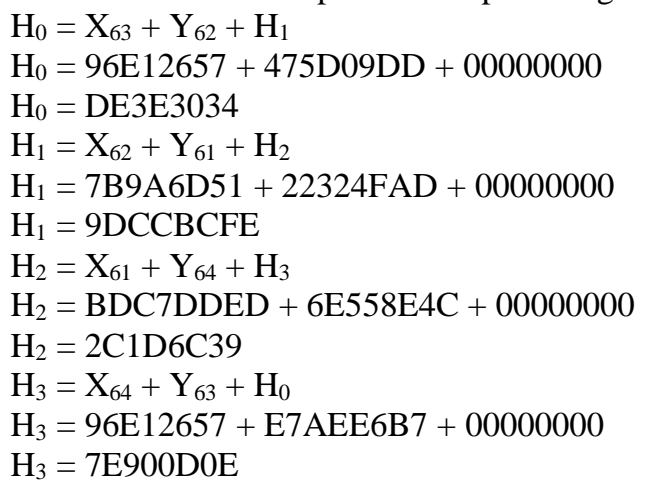

Sehingga keluaran dari nilai hash nya adalah DE3E30349DCCBCFE2C1D6C397E900D0E, nilai ini lah yang dijadikan acuan untuk menghapus file $p d f$, jika ada lebih dari satu file pdf yang memiliki nilai hash yang sama.

\section{KESIMPULAN}

Dari hasil penulisan dan analisa dari bab-bab sebelumnya, maka dapat diambil kesimpulan, dimana kesimpulankesimpulan tersebut kiranya dapat berguna bagi para pembaca, sehingga penulisan skripsi ini dapat lebih bermanfaat. Adapun kesimpulan-kesimpulan tersebut adalah sebagai Pencarian file pdf yang ganda atau duplikat di dalam sebuah media penyimpanan dapat dilakukan dengan memberikan identitas dari setiap file pdf menggunakan fungsi hash sehingga tidak perlu membuka dan membaca isi file pdf satu persatu Algoritma fungsi hash RIPEMD-128 dapat digunakan untuk merepresentasikan isi dari file pdf sehingga dapat digunakan untuk membandingkan file pdf yang ganda atau duplikat.

\section{REFERENCES}

[1] Shrivastava, "Keamanan," 2016.

[2] J. W. \&. Sons, "Kriptgrafi," 1996.

[3] H. Dobbertin, A. Bosselaers dan B. Preneel, “A Strengthened Version of RIPEMD,” Springer, Belgium, 1996.

[4] T. Peyrin, "Cryptanalysis of Full RIPEMD-128," Journal of Cryptologi, vol. III, no. 12, pp. 927-951, 2015.

[5] Y. Wicaksono, Seri Penuntun Praktis Membongkar File PDF, Jakarta: Elex Media Komputindo, 2013.

[6] S. Patil, N. Jagtap, S. Rajput dan R. Sangore, “A Duplicate File Finder System,” International Journal of Science Spirituality Business and Technology, pp. 10-14, 2017. 